\title{
Aptitude Suicide? Issues and Challenges of Island Tourism Management in Gili Trawangan, Indonesia
}

\author{
Putu Diah Sastri Pitanatri \\ Hospitality Department \\ Sekolah Tinggi Pariwisata Nusa Dua Bali \\ Bali, Indonesia \\ diahsastri@gmail.com
}

\begin{abstract}
As the sector of the future, tourism changes lives. Gili Trawangan, an island that was once uninhabited became a spotlight; an undeniably top-notch destination for island hops of millennial tourists when visiting Indonesia. Although there is a substantial increase in community welfare, other two aspects of sustainability: socio-culture and environment have risen severe issues and challenges.

Using the elements of sustainability through case studies of several island management in Indonesia, this paper critically reviews the impact of tourism on Gili Trawangan. The concepts of three elements of sustainability and the tree analogy, become the main key concept of this article. Hence, challenges which occur in this island should then raise awareness of future tourism management of other small islands in Indonesia. Tourism should not be a suicide; but should encourage and fosters sustainability in the destination.
\end{abstract}

Keywords. island, tourism, sustainability, Gili Trawangan

\section{INTRODUCTION}

Tourism island management is essential for the development of island destinations. As an integral part of tourism development in West Nusa Tenggara, Gili Trawangan has significantly generated more than one-third of foreign exchange from tourism (National Statistical Bureau; 2017). In various publications also mentioned various positive implications obtained from the implementation of tourism in the destination such as the expansion of employment, the decline in poverty and the area. Strong economic impacts towards the practices of community-based tourism in the island. Direct and indirect impacts; affect even those who are not directly involved with tourism businesses (Pitanatri, 2018).

In Indonesia, tourism growth has to boost up to 25.68 percent in 2017; confirming it as a "new star" of Indonesia's economy. Compared to the ASEAN, tourism growth rate is only at seven percent. The number is 3.5 times higher and four times higher than the global growth rate which is at 6.4 percent (JakartaPost, 2017). To contribute even further, the government has also appointed tourism as a leading sector and the nation's main economic source. The initiative also comes in officiating the $10 \mathrm{New}$ Priority Destinations, also known as 10 New Bali's, comprising Lake Toba in North Sumatra, Tanjung Kelayang in Bangka Belitung, Tanjung Lesung in Banten,
Thousand Islands in DKI Jakarta, Borobudur in Joglosemar, Bromo - Tengger - Semeru in East Java, Mandalika in Lombok, Komodo and Labuan Bajo in East Nusa Tenggara (NTT), Wakatobi in Southeast Sulawesi and Morotai in North Maluku.

In this island, tourism has significantly increased employment opportunities. The island also attracts labor from the neighbouring island like Lombok and Gili Air. These jobs varied from low-wage entry-level to highpaying professional positions in management and technical fields. This opportunity has generated income and raise standards of living in Gili Trawangan. Diversification of jobs created by the tourism sector also fosters local communities that are possibly dependent on only one industry. Likewise, in this island was once made their living as fisherman and farmers have now become professional in the tourism and hospitality sector.

As tourism grows, additional opportunities are also flourishing. Since the early nineties, this island also opens up for investment, development, and infrastructure spending. Positive growth induces improvements in public utilities such as water, sewer, lighting, and landscaping. Such improvements benefit tourists and residents alike. Likewise, tourism encourages improvements in transport infrastructure resulting in upgraded roads and international airports which allows international traveller flew directly to Lombok. Tourism encourages new elements to join the retail mix, increasing opportunities for shopping and adding healthy competitiveness induced by local communities.

Even so, it is important to note that the tourism industry is based on people and places and the interaction between them (Hanafiah, Azman, Jamaluddin, \& Aminuddin, 2016). This growth has now contributed to new challenges as there are numerous debates on the effectiveness of sustainable policy in managing island tourism development including Gili Trawangan. Previous research has explicitly confirmed problems in the management of Gili Trawangan like land abduction (Asikin, 2014), environmental issue (Afifi, 2000; Budilestari, Hutomo, \& Ardiwidjaja, 2014), and business related issues (Dewanta \& Fadiar, 2015). Likewise, it is 
important that the development of this island remain sustainable.

There have been many examples of islands in the world that have become unsustainable due to poor tourism management. Tourism's economic benefits have been challenged because of the negative environmental and social impacts observed in some islands (De Albuquerque and McElroy 1992; Gossling 2001; Simpson and Wall 1999; Weaver 2001).

When considering the economic impacts of tourism, it is indispensable to understand that tourism businesses often include a significant number of low-paying jobs, often at minimum wage or less. These low-paying jobs are often used by students or fresh graduate to gain experiences before getting their hands-on to the real jobs in the tourism sector. As a conclusion, the rapid tourism growth has also created population pressure, stemming from the increase not only permanent residents but also temporary workers.

If referring to the initial conditions, Gili Trawangan is an uninhabited island which was originally an exile location for detainees and former prisoners. The local government then transform the island into coconut plantation with only several houses inhabited the island. After a German traveler and writer, name Peter Ram in 1978 stayed for a few days on this island then wrote his experience that became a success in German Guidebook. Tony Wheeler, the founder of Lonely Planet himself also visited the island in the same year and made a special issue of Bali and Lombok; highlighting on The Gili islands (Pitanatri, 2018). Lonely Planet then started it's annual issue and Bali and Lombok became a success in 1985. After becoming a bestseller guidebook, travellers tend to visit Gili Trawangan and in 1986, the island is flooded with tourist and travellers. It was the beginning of tourism in the island.

Gili Trawangan itself began to grow after there was an expression from West Lombok to North Lombok. Autonomy and regional expansion that occurred at that time made this destination able to develop itself and its potential. In 1988-1989, UNDP as a consultant to the Ministry of Tourism, Post and Telecommunications designed that there were only 350 rooms of rooms available for each island. Unfortunately the recommendation was changed by the head of regent Mujitahid in the early nineties.

Today, technology and Millenials plays an important role in promoting the island as a tourist destination. Through their blogs and social media, they created imagination to tourist even before their visit. The tourist does not choose a destination only because of the beautiful landscapes or culture that it has, but more into the unknown of the destination. They prefer getting access online of what to do, what to visit and how to get to a place by using technologies. In this sense, technology integrates the global experience into the destination (Wethner et al., 2015). Based on this approach, tourists actively engage with service providers and collaborate in co-creating their own experiences, which frequently contributes directly to providing innovation (Buhalis and Amaranggana, 2014).

Technological developments and information flow that are so fast supported by the Ministry's policy of developing destinations through the "10 Bali Baru" program have implications for the acceleration of the development of destinations as if forced. On the one hand, this "coercion" is needed so that the following program acceleration with the readiness of the resources is running in synergy. But undeniably, there are spaces that are untouched and have the potential to weaken the carrying capacity of the destination.

Despite international recognition that the tourism industry needs to move towards sustainability, action has been mainly conceptual to date and has not translated into industry-wide practice (Pryce 2001). It is therefore important to understand why the move towards sustainability has been relatively limited in the tourism industry in order to determine how this industry can be encouraged to introduce more sustainable practices (Diamantis 1999; Bramwell and Alletorp 2001; Pryce 2001; Dodds 2005)

This paper is trying to criticize the mismanagement of destination so it will not be repeated. The aim of this-this paper to minimize aptitude suicide in making tourism as a scapegoat for developing destinations. Tourism should not be dichotomized and made to clash with the many interests that derive profits from this sector.

\section{METHODOLOGY}

This study uses a qualitative approach where literature review is strengthened by in-depth interviews with resource persons from various stakeholders. In-depth interviews were also conducted with the previous and current local government. This consisted of three interviews, one was conducted with the previous head of the island, one with the current head of the island and one with the advisor as well as the second generation who develop the island from the very beginning. The interviews discussed the history of tourism initiatives on the island, identified barriers to implementing sustainable tourism management, innovative means, and their perspective on the uprising issues. Interviews were also conducted with tourists, employees and the local community on the island.

\section{RESEARCH OUTCOMES}

There are three findings in this study that are interesting enough to be explored further. All three are the critical appreciation from the local community and stakeholders; which includes changes in livelihood, questions on culture and LGBT issues. 


\section{A. Changes in Livelihood}

How local community lived on this island can be seen as an interesting contradiction. On the one hand, changes in lifestyle can be an adaptation process so that people benefit more from the times. Without a change in lifestyle, the destination will likely run stagnant without significant development.

However, changes in livelihood will have implications for a changing culture. Local people not only have improved living standards but also increased skills. However, after tourism, the main sectors that were prioritized on the Gili began to be abandoned. Jobs like fishermen and farmers are now lack of interest from the younger generation - most of this younger generation take it's path to tourism; a sector that was renowned for its ability in making "easy money" in the island.

What happens then, filtration of changes seems so difficult to do. As one example, when the Lombok was shaking by 7.2 scale earthquake in July 2018, the island was destroyed. Like a dead island, for several weeks it became uninhabited due to the Tsunami issue. The attachment of local communities to tourism has implications for their livelihoods.

As much attached to this sector, when tourism is suspended, the population does not have a source of income. When they wanted to go farming, their land has been sold and transformed into accommodation. When they tend to go fishing, their skills have been eroded. In the long run, almost all basic needs, especially food, are imported from other islands such as Lombok and Bali. This certainly brings the impact of the high cost of staple goods on the island.

Transportation is also the main reason for almost all of the basic needs of the Gili Islands to be expensive. For example, to bring goods to these three islands must go through sea trips, porters and cidomo (horse cart). In addition, local transportation requires that there is no motorized vehicle on this island, on the one hand, will impact the cidomo transportation monopoly on the island. Prices per cidomo even up to one billion rupiahs, even more expensive than high-end cars in Indonesia. Labor costs are also expensive, resulting in inexpensive prices. The price of each of these basic necessities becomes extremely expensive compared to the neighbouring island

A market system that ultimately makes goods expensive so that people living on this island are accustomed to prices for tourists. Like some world tourism destinations such as Italy, local people also have to buy expensive basic necessities. This also resulted in a lot of business ventures that deliberately repatriated their workers to Lombok's main island to save costs. Greater demand for goods, services, land, and housing also increase prices that in turn increase the cost of living on the island.

Tourism development in the Gili Islands also has implications for the development of tourism in Labuan Bajo. The beginning of the existence of reef explorer and island hopping between these islands began with a squid trader named Haji Kahar who collaborated with local communities in Gili Trawangan in the early nineties. At that time this collaboration shaped a 4D3N trip package to Labuan Bajo. The initial reason was only that after trading squid to Gil Trawangan, the ship back to Labuan Bajo would be empty. Therefore there are initiations for students and tourists using "Pinisi" (traditional fishing boats) on their way home. The initiative was followed by one of the Komodo travel pioneers named Haji Nasir who later made an island hopping package which travels from Gili Trawangan - Labuan Bajo and Komodo.

Changes in livelihood also occur with "marginalized" local communities into non-tourism zoning. As mentioned earlier, local people who were originally fishermen living on the shore, now have to occupy locations in the middle of the island because land prices are not affordable anymore. Luckily for those who have a land inheritance. Many of these local residents who eventually have homestays and boarding houses as a competitive venture from their main job.

Per acre the price is already 150 (million rupiah) and above. The land by the beach is even crazier... The price can be more than 500 million per acresomething that we cannot afford.

Haji Ahmad Rifai, 2018

Prices of land are soaring, which has implications for changes in local people's livelihoods. Very few young people want to become farmers and fishermen. Although they are generally schooled in pesantren (religion school), their goal is to work in tourism. The average community in Gili Trawangan also has a side business ranging from homestay room rentals, business in the field of boat trips, bicycle rentals, laundry businesses and other businesses that support tourism.

This advanced thinking came from the village apparatus who stated that in fact $70 \%$ of the local people must have a business. There must be an advantage for them so they become owners of this destination. On the one hand even though there are non-local investors, don't make them competitors. Make friends as hand-in-hand to build this destination. Hence, it is undeniable that the transition from subsistence to a cash economy, is undergoing substantial threats to agriculture and fishing which was previously the main occupation of local communities in Gili Trawangan. 


\section{B. Where is Culture?}

This question was engraved when this research was conducted. During the observation and data search, culture can hardly be found on this island. Tourism attractions are more focused on party and nightlife which is not a local culture at all. Indeed, the island is basically intended for marine tourism such as snorkeling, jet skiing and various activities and sea sports. In various traveller's sites (TripAdvisor, 2018; Lonely Planet, 2017; Adventure in You, 2017 dan TripCanvas, 2016) not a single website highlighted culture as a point of interest for tourists visiting Gili Trawangan.

Local culture is so disguised by the culture of tourists who grow and develop in this destination. Local people who are part of the Sasak and Bugis tribe is lack of authenticity. Culture is not visible on this island; dominated by foreign culture. This change is not entirely this is a result of tourism development, as the island was not designated for cultural activities

From interviews conducted with village elders, it was stated that Gili Trawangan was not developed as a cultural tourism destination but a marine destination. He also explicitly stated that on Gili Air and Gili Meno - as the islands where most residents lived- there is no indigenous culture of the Gili islands.

That culture is not our original culture. We are actually Bugis native, but few came from Sasak tribes. There is a Sireh dance but it's not staged for tourists. What still exists today is only Gambus music. I think that is the only culture we have.

Haji Ahmad Rifai, 2018

When interviewed further, the process of forming Gili Trawangan also cannot be separated from the initiation of local communities. Haji Rifai which is the second generation that occupies this island in 1989-1991 sells tickets for staging arts and culture on Gili Trawangan. This was conducted in order to attract visitors to visit Gili Trawangan. All artists were from Lombok and Pemenang island, of which at that time the famous performance was Rudat Dance. After a while, the performance was carried out, he said that the profits were dominated by dancers so the cultural performances were stopped. Since that time there has never been any initiation to carry out a cultural performance on Gili Trawangan.

This is in contrast to Bali which puts culture as the main attraction of the island. Tourism has even become a catalyst for the cultural drive that also invites young people to participate in preserving culture. Like the infamous "Rejang Renteng" dance that became popular in 2018 after becoming a tourist attraction during the opening of many cultural festivals in Bali.

Indeed, not all tourist destinations in Indonesia must be imprinted on culture, but it is unusual for an island surrounded by a thick culture to become an island that does not develop its culture at all. To many researcher, when there is no culture will there is no sustainability.
The social and cultural changes of tourism warrant careful consideration, as impacts can either become assets or detriments to local communities. Tourists may bring diverse values to the community and influence behaviours and family life. On the other hand, individuals and the collective community might try to please tourists or adopt tourist behaviours. The interactions between residents and tourists can impact creative expression by providing new opportunities (positive) or may also stifling individuality with new restrictions (negative). Increased tourism can push a community to adopt different moral conduct such as improved understanding between sexes (positive) or increased illicit drug use (negative). Like in Bali, traditional ceremonies may be renewed and revived by tourist interest or lost in alternative activities.

Tourism can improve the quality of life in an area by increasing the number of attractions and recreational opportunities. Tourism also fosters resident's opportunities to meet new people from around the world, make friendships, and expose themselves to new perspectives. Experiencing different cultural practices enriches experiences, and increases appreciation for different approaches to living. Often, host cultures are revived by reawakening cultural heritage as part of tourism development, which increases the demand for historical and cultural exhibits. This interest by tourists in local culture and history provides opportunities to support the preservation of historical artefacts and architecture. At the same time, tourism also often promotes higher levels of psychological satisfaction from opportunities created by tourism development and through interactions with travellers.

Tourism can come to a community with a dark social and cultural side, too. Hotels, restaurants, and shops can push tourism development into residential areas, forcing changes and movement of the local community. These condition may affect the physical structure of a community. Development of tourist facilities in prime locations may cause locals to feel excluded from those resources. The "demonstration effect" of tourists (residents adopting tourist behaviours) and the addition of tourist facilities may alter customs, such as dating habits, especially those of a more structured or traditional culture.

However, where culture is part of the tourist attractions, over-amplification of cultural traits and the creation of "new" cultural traits to satisfy tourist tastes may create a phoney culture. Residents may experience a sense of exclusion and alienation over planning and development concerns. They may feel a loss of control over the community's future as "outsiders" take over establishments and new development. Over-dependence on non-local developers and an influx of outside businesses creates a sense that the community is being manipulated and exploited by outsiders for the sole benefit of those developers or business people. Hotels built in monolithic cubes or restaurants with standardised franchise designs might clash with local standards and disrupt the aesthetic appearance of the community, damage unique community character, and spread "sameness." 


\section{Halal tourism versus Gay Tourism}

The echo of Lombok as one of the halal destinations in Indonesia increased after the success of this destination became a winner in the World Best Halal Tourism Destination in Abu Dhabi in 2016. This victory then continued with various programs to further strengthen the existence of destinations, especially for the Middle East market.

Some programs that were launched by the central government through the tourism ministry together with local governments include the expansion of Lombok's international airport by opening direct flights from world destinations such as Dubai and Abu Dhabi. As of 2018, there are 305 increase of international airlines that make direct flights to Lombok International Airport.

The dichotomy happened after the Gili islands crowned as one of the best destinations for Lesbian, Gay, Bisexual, and Transgender (LGBT) Travelers. Gili Trawangan according to some media is also referred to as one of the "gay-friendly" destinations in Indonesia. The Gili is considered a "separate" island from Lombok, which is more like Bali regarding its acceptance of the people that up to this point is still very sensitive and controversial in Indonesia.

Unlike the "parade for caught thieves" on the island, no special local law prohibits LGBT. Whereas if it refers to Shari'a law which is partially enforced in Lombok, a conservative approach should apply to this island as well. As a very sensitive issue, fear was felt by elders of the younger generation would be affected and become part of the group.

If possible, please don't. It does not fit the teachings of Islam; our Prophet forbids love between the same gender. It is haram (illegal)

Head of Village, Suburuddin, 2018

To "fortify" their young generation, the local mosque then applies religious attempts where $r$ lectures and various advice following Islamic Shari'a. Until today, the locals themselves do not really "care" about the LGBT activities on this island. The activities are so discreet that the locals consider this phenomenon not as a dichotomy to be unsettling.

The LGBT phenomenon has been exposed in the world. For example, there's TravelByInterest.com site that offers Gili Trawangan as one the best Gay Destination in South East Asia. On the street and public areas, can also be found tourists freely with the same gender expressing love to each other. What is the typology, the preference of this type of tourist is how the acceptance of the local community towards this phenomenon becomes a separate study that can be further exploration and observation? This phenomenon is indeed worth studying and is a limitation in this initial research.

\section{CONCLUSION.}

Island tourism management, which is the priority of managing this destination, is indeed crucial to be managed better. The synergy between the local community, government and the private sector is needed so that the development of this destination does not become an aptitude suicide. As being said, tourism is a future sector that is not only able to develop destinations but has a substantial contribution to. The government and entrepreneurs and associations of employers must be synergized to develop this island in a sustainable way.

\section{REFERENCES}

Adventure in You. 2017. Things To Do in The Gili Islands. Retrieved from https://www.adventureinyou.com/indonesia/things-to-do-inthe-gili-islands/. 22 October 2018.

Afifi, M. (2000). Community-Based Management for Coral Reef Conservation In the Gili Islands of Lombok Indonesia. Management, 1-9.

Asikin, Z. (2014). Penyelesaian Konflik Pertanahan Pada Kawasan Pariwisata Lombok (Studi Kasus Tanah Terlantar di Gili Trawangan Lombok). Jurnal Dinamika Hukum, 14(654), 239250.

Bramwell, B. and L. Alletorp (2001). "Attitudes in the Danish Tourism Industry to the Roles of Business and Government in Sustainable Tourism." International Journal of Tourism Research 3: 91-103

Budilestari, N., Hutomo, M., \& Ardiwidjaja, R. (2014). Permasalahan Lingkungan Di Sempadan Pantai Taman Wisata Perairan Gili Trawangan, Nusa Tenggara Barat. Jurnal Kepariwisataan Indonesia, 9(1), 91-107.

Buhalis, D. and Amaranggana, A. (2014), "Smart tourism destinations enhancing tourism experience through personalisation of services", in Tussyadiah, I. and Inversini, A. (Eds), Information and Communication Technologies in Tourism 2015, Springer International Publishing, Lugano, pp. 377-389.

Dewanta, A. S., \& Fadiar, L. M. S. A. (2015). Permintaan Rekreasi Gili Trawangan Dan Pembangunan Daerah. Jurnal Inovasi Dan Kewirausahaan, 4(3), 130-137.

Diamantis, D. (1999). "Green Strategies for Tourism Worldwide." Travel and Tourism Analyst 4: 89-112.

Dodds, R. (2003). Developing New Markets for Traditional Destinations: Is Sustainable Tourism Policy a Successful Option for Creating New Markets? London, University of Surrey: 10.

De Albuquerque, K., and J. McElroy. 1992 Caribbean Small Island Tourism Styles and Sustainable Strategies. Environmental Management 16:619-632

Gossling, S. 2001 Tourism, Economic Transition and Ecosystem Degradation. Tourism Geographies 3:430-453.

Hanafiah, M. H., Azman, I., Jamaluddin, M. R., \& Aminuddin, N. (2016). Responsible Tourism Practices and Quality of Life: Perspective of Langkawi Island communities. Procedia - Social and Behavioral Sciences, 222, 406-413. https://doi.org/10.1016/j.sbspro.2016.05.194

JakartaPost. 2017. Tourism Becomes New Star of Indonesia's Economy. Retrieved http://www.thejakartapost.com/travel/2017/10/18/tourismbecomes-new-star-of-indonesias-economy-report.html October 2018

Jones Around The World. 2017. Retrieved from https://www.jonesaroundtheworld.com/10-amazing-things-to-doon-gili-trawangan/. 22 October 2018.

Lonely Planet. 2018. Top Things to Do in Gili Islands. Retrieved from https://www.lonelyplanet.com/indonesia/gili-islands/top-things-todo/a/poi/356596. 22 October 2018.

Pitanatri, P. D. S. (2018). Learn to Earn: Assessing Economic Impact of Community Based Tourism in Gili Trawangan, Indonesia. 
International Journal of Multidisciplinary Educational Research, $7(1), 220-236$

Pryce, A. (2001). "Sustainability in the Hotel Industry." Travel and Tourism Analyst 6: 3-23

Simpson, P., and G. Wall. 1999 Consequences of Resort Development: A comparative study. Tourism Management 20:283-296

Tripadvisor 2018. Things to Do in Gili Trawangan. Retrieved from https://www.tripadvisor.com/Attractions-g664666-Activities-

Gili_Trawangan_Gili_Islands_Lombok_West_Nusa_Tenggara.html. 22 October 2018

TripCanvas. 2016. Things To Do in Gili Islands. https://indonesia.tripcanvas.co/lombok/things-to-do-gili-islands/. 22 October 2018.

Neuhofer, B., Buhalis, D. and Ladkin, A. (2014), "A typology of technology-enhanced tourism experiences", International Journal of Tourism Research, Vol. 16 No. 4, pp. 340-350.

Weaver, D. 2001 Mass and Alternative Tourism in the Caribbean. In Tourism and the Less Developed World, D. Harrison, ed., pp. 161174. Wallingford: CABI

Wethner, H., Alzua-Sorzabal, A., Cantoni, L., Dickinger, A., Gretzel, U., Jannach, D., Neidhardt, J., Pröl, B., Ricci, F., Scaglione, M., Stangl, B., Stock, O. and Zanker, M. (2015), "Future research issues in IT and tourism. A manifesto as a result of the JITT workshop in June 2014, Vienna", Journal of Information and Technology in Tourism, Vol. 15, pp. 1-15. 